\title{
Meningkatkan Keaktifan dan Hasil Belajar Melalui Penerapan Model Pembelajaran Wide Game pada Peserta Didik Kelas VIID SMP Negeri 13 Tegal
}

\author{
Suharni \\ SMP Negeri 13 Tegal, Kota Tegal Provinsi Jawa Tengah \\ Corresponding Author. Email: rosyharni@gmail.com
}

\begin{abstract}
The purpose of this study is to increase the activeness and learning outcomes of students through the Wide Game learning model in economic activity material. This research method using descriptive method. The subjects in this study were 31 students of class VIID SMP Negeri 13 Tegal. The research instrument used a questionnaire and data analysis techniques using descriptive analysis. The results of this study indicate that there is an increase in the activeness and learning outcomes of students through the Wide Game learning model in economic activity material. This is evidenced by the data in the first cycle with an average value of 70.97 and those who completed 58.04\% increased the average value of 81.23 and those who completed were $87.10 \%$ in the second cycle. This increase is also accompanied by changes in behavior, students are more active, and respect others in doing tasks.
\end{abstract}

\begin{abstract}
Abstrak: Tujuan penelitian ini adalah untuk meningkatkan keaktifan dan hasil belajar peserta didik melalui model pembelajaran Wide Game pada materi kegiatan ekonomi. Metode penelitian ini menggunakan metode deskriptif. Subyek dalam penelitian ini adalah peserta didik kelas VIID SMP Negeri 13 Tegal yang berjumlah 31 orang. Instrumen penelitian ini menggunakan angket dan tehnik analisa datanya menggunakan analisis deskriptif. Hasil penelitian ini menunjukkan bahwa terdapat peningkatan keaktifan dan hasil belajar peserta didik melalui model pembelajaran Wide Game pada materi kegiatan ekonomi. Hal ini dibuktikan dari data siklus I nilai rata-rata 70,97 dan yang tuntas 58,04\% meningkat nilai rata-ratanya 81,23 dan yang tuntas $87,10 \%$ di siklus II. Peningkatan ini juga disertai dengan perubahan perilaku, peserta didik semakin aktif, dan menghargai orang lain dalam mengerjakan tugas.
\end{abstract}

\author{
Article History \\ Received: 22-12-2020 \\ Revised: 02-01-2021 \\ Published: 07-01-2021
}

\section{Key Words:}

Activeness, Learning

Outcomes, Wide Game.

\author{
Sejarah Artikel \\ Diterima: 22-12-2020 \\ Direvisi: 02-01-2021 \\ Diterbitkan: 07-01-2021
}

\section{Kata Kunci:}

Keaktifan, Hasil Belajar, Wide Game.

How to Cite: Suharni, S. (2021). Meningkatkan Keaktifan dan Hasil Belajar Melalui Penerapan Model Pembelajaran Wide Game pada Peserta Didik Kelas VIID SMP Negeri 13 Tegal. Jurnal Paedagogy, 8(1). doi:https://doi.org/10.33394/jp.v8i1.3278

\section{Pendahuluan}

Belajar merupakan kegiatan utama dari keseluruhan proses pendidikan di sekolah yang bertujuan untuk menghasilkan perubahan tingkah laku. Perubahan itu meliputi kognitif, afektif dan psikomotor (Nurhayati, Mulyani, \& Roshida, 2020). Kegiatan pembelajaran memerlukan keaktifan belajar, partisipasi dan komunikasi interaktif antara guru dan siswa. Aktivitas belajar dirancang sedemikian rupa sehingga menghasilan pembelajaran yang di tentukan. Keberhasilan dalam proses pembelajaran dapat dilihat dari pemahaman konsep, penguasaan materi dan prestasi belajar (Fajuri, 2019; Asni, 2017; Pratini, 2015).

Menurut Suprijono (2010) menyebutkan bahwa mengaktifkan belajar siswa dalam kegiatan pembelajaran merupakan salah satu cara menghidupkan dan melatih memori siswa agar bekerja dan berkembang secara optimal. Sedangkan menurut Sobry Sutikno (2013) bahwa dalam proses pembelajaran, berhasil atau tidaknya pencapaian tujuan banyak dipengaruhi oleh bagaimana proses belajar yang dialami oleh siswa. Keaktifan itu beragam bentuknya, mulai dari kegiatan fisik yang mudah kita amati sampai kegiatan psikis yang susah diamati (John Dewey, dalam Dimyati dan Mudjiono, 2002). Dari beberapa definisi di 
atas dapat disimpulkan bahwa keaktifan belajar merupakan keseluruhan kegiatan belajar yang dilakukan oleh siswa untuk menghasilkan perubahan pengetahuan-pengetahuan, nilai-nilai sikap, dan ketrampilan sebagai bentuk latihan yang dilaksanakan secara sengaja. Proses belajar yang dilakukan oleh seseorang tidak akan terlepas dari adanya keaktifan siswa dalam proses pembelajaran baik yang bersifat fisik maupun mental. Oleh karena itu, keaktifan belajar merupakan hal yang sangat penting bagi peserta didik. Karena dengan aktif dapat menghasilkan perubahan-perubahan pengetahuan, sikap dan ketrampilan.

Hasil belajar merupakan hasil yang diperoleh siswa dalam melakukan proses pembelajaran dikelas (Suryani, 2018). Purwanto (2010) menjelaskan bahwa hasil belajar merupakan pencapaian tujuan pendidikan siswa yang mengikuti proses belajar mengajar, Hasil belajar merupakan realisasi tercapainya tujuan pendidikan, sehingga hasil belajar yang diukur sangat tergantung pada tujuan pendidikannya. Senada dengan Purwanto, Hamalik (2013) menyatakan bahwa hasil belajar adalah bukti bahwa seseorang telah belajar, yaitu terjadinya perubahan tingkah laku pada orang tersebut. Tingkah laku manusia terdiri dari sejumlah aspek. Hasil belajar akan tampak pada setiap perubahan pada aspek-aspek berikut ini : 1). pengetahuan, 2) pengertian, 3) kebiasaan, 4) keterampilan, 5) apresiasi, 6) emosional, 7) hubungan sosial, 8) jasmani, 9) etika (budi pekerti), dan 10).Sikap. Dari beberapa pengertian dapat disimpulkan hasil belajar adalah hasil yang diperoleh siswa selama belajar dan dapat diwujudkan dalam nilai pengetahuan.

Menurut Daryanto (2012) bahwa model pembelajaran merupakan kerangka konseptual yang melukiskan prosedur yang sistematis dalam mengorganisasikan pengalaman belajar untuk mencapai tujuan belajar tertentu dan berfungsi sebagai pedoman bagi para perancang pembelajaran dan para pengajar dalam merencanakan aktivitas belajar mengajar. Sedangkan menurut Trianto (2007) model pembelajaran kooperatif adalah sebuah kelompok strategi pengajaran yang melibatkan siswa bekerja dengan berkolaborasi untuk mencapai tujuan bersama.

Wide game adalah permainan besar di luar ruangan dengan wilayah yang relatif luas yang diikuti oleh dua atau lebih regu/tim. Wide Game bersifat permainan kompetisi/pertandingan antar tim atau antar inidividu, sehingga antara tim yang satu dengan yang lain berusaha untuk memenangkan pertandingan (Ensiklopedia Pramuka, 2013). Wide Game dalam hal ini dipakai sebagai model pembelajaran yang memanfaatkan luar ruang kelas yaitu taman sekolah dan lapangan. Tekniknya dengan dibuat 6 atau 8 pos yang menyebar, tiap-tiap pos terdapat instruksi yang harus dikerjakan oleh regu/kelompok.

Dalam penelitian tindakan kelas (PTK), guru dapat meneliti proses pembelajaran yang dilakukan di kelasnya dengan melibatkan peserta didiknya melalui tindakan-tindakan yang telah direncanakan, dilaksanakan, dan dievaluasikan. Tujuan PTK adalah untuk mengatasi berbagai persoalan nyata guna memperbaiki atau meningkatkan kualitas proses pembelajaran di kelas (Suhardjono, 2011). Pembelajaran kooperatif dapat memperbaiki proses pembelajaran konvensional. Pembelajaran kooperatif mengacu pada pembelajaran di mana siswa bekerja dalam kelompok-kelompok kecil untuk saling membantu satu sama lainnya dalam belajar (Hamalik, dalam Hidayati, 2018). Pembelajaran kooperatif yang digunakan dalam penelitian ini adalah Wide Game. Diharapkan dengan metode ini peserta didik akan lebih aktif dan meningkat hasil belajarnya. Adapun tujuan penelitian ini adalah untuk meningkatkan keaktifan dan hasil belajar perserta didik melalui penerapan model pembelajaran Wide Game pada peserta didik kelas VIID SMP Negeri 13 Tegal. 


\section{Metode Penelitian}

Metode penelitian yang digunakan adalah penelitian tindakan kelas (PTK) dengan subyek penelitian ini adalah peserta didik kelas VIID yang berjumlah 31 orang. Model penelitian tindakan kelas ini mengadaptasi dari John Elliot dalam Subyantoro (2014) dengan model siklus setiap langkahnya sebagai berikut.

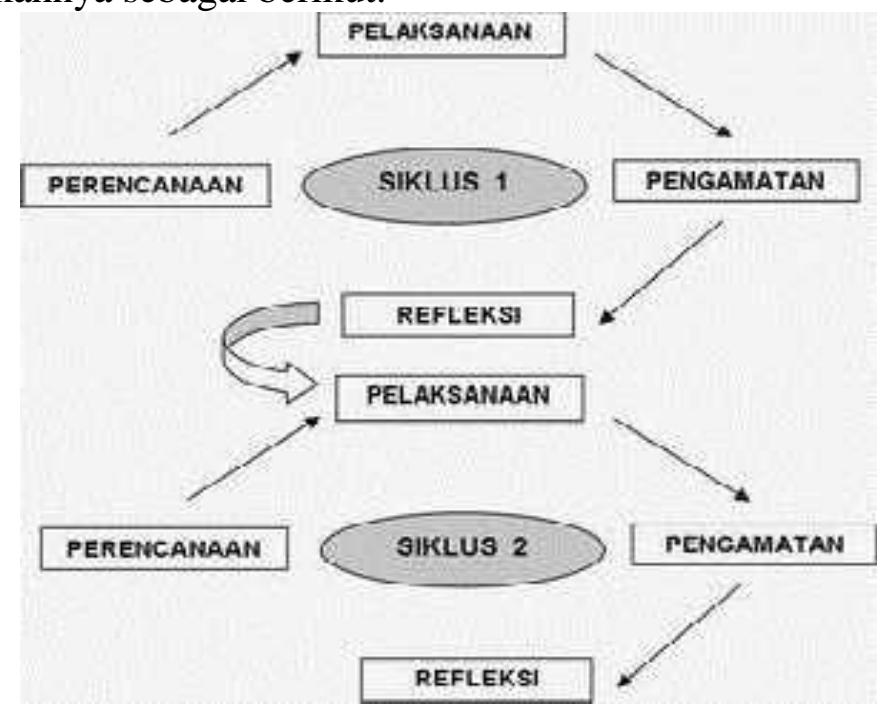

Gambar 1. Model Penelitian Tindakan Kelas

Pada penelitian ini ada 4 tahapan yang dilakukan yakni perencanaan, pelaksanaan, pengamatan, dan refleksi. Instrumen penelitian yang digunakan adalah lembar pengamatan dan lembar penilaian keaktifan belajar peserta didik. Penilaian di setiap akhir siklus digunakan untuk mengukur hasil belajar peserta didik. Tehnik analisis data penelitian ini menggunakan analisis deskriptif kualitatif dan kuantitatif.

\section{Hasil Penelitian dan Pembahasan Deskripsi Siklus I}

Dalam penelitian siklus I, keaktifan peserta didik dalam pembelajaran belum maksimal, dari 31 peserta didik baru 7 peserta didik yang sangat aktif (22,58\%), 2 peserta didik yang aktif $(6,45 \%), 10$ peserta didik cukup aktif $(32,26 \%)$ dan 12 peserta didik yang kurang aktif $(38,71 \%)$. Dari hasil penelitian dapat diketahui bahwa peserta didik kurang aktif, masih acuh atau belum bisa bekerjasama dan belum bisa menghargai pendapat temannya. Cenderung yang aktif dalam satu kelompok hanya ketua kelompoknya saja. Hasil belajar di siklus I hanya 58,04\% (18 anak yang di atas KKM) dengan nilai rata-rata 70,97.

\section{Deskripsi Siklus II}

Berdasarkan refleksi siklus I, peneliti menyusun kembali rencana pelaksanaan pembelajaran dan melaksanakan pembelajaran dengan membagi kelompok menjadi lebih kecil lagi, juga memperbaiki proses pembelajaran Wide Gamenya. Selain kelompok diperkecil juga dengan menempelkan, membahas hasil kerja kelompok di setiap pos pada papan tulis depan kelas. Pada siklus II ini menunjukkan adanya peningkatan yaitu 19 peserta didik sangat aktif $(61,29 \%), 8$ peserta didik aktif $(25,81 \%)$, hanya 2 peserta didik yang cukup aktif $(6,45 \%)$ dan 2 peserta didik kurang aktif $(6,45 \%)$. Peserta didik semakin bisa bekerjasama dengan orang lain dan semakin menghargai pendapat orang lain. Hasil belajar 
pun mengalami peningkatan dengan nilai rata-rata di siklus II ini menjadi 81,23 dan yang tuntas menjadi 27 orang $(87,10 \%)$.

Dari hasil penelitian ini menunjukkan bahwa keaktifan dan hasil belajar peserta didik melalui model pembelajaran Wide Game yang dilakukan selama dua siklus mengalami peningkatan. Peningkatan ini dapat dilihat dari keaktifan peserta didik yang diperoleh selama dua siklus sebagai berikut.

\section{Perubahan Keaktifan Peserta Didik}

Tabel 1. Keaktifan Belajar Peserta didik

\begin{tabular}{|c|c|c|c|}
\hline No. & Kriteria & Siklus I & Siklus II \\
\hline \hline 1 & Sangat aktif & $\begin{array}{c}7 \text { peserta didik } \\
(22,58 \%)\end{array}$ & $\begin{array}{c}19 \text { peserta didik } \\
(61,29 \%)\end{array}$ \\
\hline 2 & Aktif & $\begin{array}{c}2 \text { peserta didik } \\
(6,45 \%)\end{array}$ & $\begin{array}{c}8 \text { peserta didik } \\
(25,81 \%)\end{array}$ \\
\hline 3 & Cukup Aktif & $\begin{array}{c}10 \text { peserta didik } \\
(31,25 \%)\end{array}$ & $\begin{array}{c}2 \text { peserta didik } \\
(6,45 \%)\end{array}$ \\
\hline 4 & Kurang Aktif & $\begin{array}{c}12 \\
\text { peserta didik } \\
(38,71 \%)\end{array}$ & $\begin{array}{c}2 \\
\text { peserta didik } \\
(6,45 \%)\end{array}$ \\
\hline
\end{tabular}

Dari hasil angket diketahui perilaku peserta didikpun mengalami peningkatan yaitu sangat tertarik dengan Wide Game 18 orang $(58,06 \%$,) di siklus I meningkat menjadi 29 orang (93,55\%), senang belajar kelompok 19 Orang (61,29\%) di siklus I meningkat menjadi 29 orang $(93,55 \%)$, dapat bekerjasama dengan temannya 20 orang $(64,52 \%)$ di siklus I menjadi 29 orang $(93,55 \%)$, mau menghargai temannya 21 orang $(67,74 \%)$ di siklus I meningkat menjadi 26 orang $(83,87 \%)$, dan sangat senang pembelajaran IPS dengan model pembelajaran Wide Game adalah 19 orang $(61,29 \%)$ di siklus I meningkat menjadi 29 orang $(93,55 \%)$

\section{Perubahan Hasil Belajar Peserta Didik}

Berdasarkan hasil tes yang diperoleh di setiap akhir siklus didapatkan data sebagai berikut:

Tabel 2. Hasil Belajar Peserta Didik

\begin{tabular}{|c|l|c|c|}
\hline No. & \multicolumn{1}{|c|}{ Kriteria } & Siklus I & Siklus II \\
\hline \hline 1 & Nilai Tertinggi & 90 & 92 \\
\hline 2 & Nilai Terendah & 45 & 70 \\
\hline 3 & Nilai Rata-rata & 70,97 & 81,23 \\
\hline 4 & $\begin{array}{l}\text { Pencapaian KKM } \\
\geq 5\end{array}$ & $\begin{array}{c}18 \text { peserta didik } \\
(58,04 \%)\end{array}$ & $\begin{array}{c}27 \text { peserta didik } \\
(87,10 \%)\end{array}$ \\
\hline 5 & $\begin{array}{l}\text { Peningkatan antar } \\
\text { siklus }\end{array}$ & \multicolumn{2}{|c|}{$29,06 \%$} \\
\hline
\end{tabular}

Hasil belajar mengalami peningkatan dari siklus I 70,97 meningkat menjadi 81,23 di siklus II. Hal ini berarti terjadi peningkatan nilai rata-rata nilai sebesar 10,26 dari siklus I ke siklus II. Sedangkan peserta didik yang sudah mencapai KKM $\geq 75$ dari siklus I 58,04\% (18 peserta didik) meningkat menjadi 87,10\% (27 peserta didik) di siklus II. Peningkatan jumlah peserta didik yang memenuhi KKM dari siklus I ke siklus II meningkat sebesar 29,06\%. Hal ini menunjukkan bahwa model pembelajaran Wide Game mampu meningkatkan hasil belajar peserta didik. Jika hal ini dikonfirmasikan dengan faktor kesiapan belajar dalam teori belajar 
yang ditulis Oemar Hamalik (2013) bahwa peserta didik yang telah siap belajar hasil belajarnya akan baik. Sebaliknya jika faktor kesiapannya rendah hasil belajarnya cenderung rendah.

\section{Kesimpulan}

Berdasarkan penelitian ini dapat disimpulkan bahwa: 1) melalui model pembelajaran Wide Game terbukti dapat meningkatkan keaktifan belajar peserta didik, perkembangan keaktifan peserta didik dari $29,03 \%$ di siklus I dan meningkat menjadi $87,09 \%$ pada siklus II, sehingga besarnya peningkatan siklus I dan II adalah mencapai 58,06\%; 2) model pembelajaran Wide Game terbukti juga dapat meningkatkan hasil belajar peserta didik. Hal itu dapat dilihat dengan adanya peningkatan nilai rata-rata kelas yang dicapai oleh peserta didik, yaitu dari nilai rata-rata 70,97 siklus I dan pada siklus II nilai rata-ratanya meningkat menjadi 81,23 . Sedangkan peserta didik yang sudah mencapai KKM $\geq 75$ dari menjadi $58,04 \%$ (18 peserta didik) di siklus I dan di siklus II menjadi 87,10\% (27 peserta didik).

\section{Saran}

Berdasarkan hasil penelitian ini dapat disampaikan saran bahwa guru IPS dapat menggunakan model pembelajaran Wide Game untuk meningkatkan keaktifan dan hasil belajar peserta didik, sehingga peserta didik bisa lebih termotivasi untuk belajar IPS dan berimplikasi pada prestasi belajarnya dikelas, selain itu bagi pihak sekolah juga untuk memotivasi guru agar lebih kreatif dalam mengajar.

\section{Daftar Pustaka}

Anita Lie. (2008). Cooperative Learning. Jakarta: PT Grasindo.

Asni, H. (2017). Upaya Meningkatkan Aktivitas dan Hasil Belajar Peserta Didik Melalui Penerapan Pendekatan Cooperative Learning Tipe Jigsaw di Kelas III-A SD Negeri 2 Cakrangeara. Jurnal Kependidikan: Jurnal Hasil Penelitian dan Kajian Kepustakaan di Bidang Pendidikan, Pengajaran dan Pembelajaran, 3(2). doi:https://doi.org/10.33394/jk.v3i2.567

Daryanto. (2012). Inovasi Pembelajaran Efektif. Bandung:Ymara Widya

Dimyati, Mudjiono. (2002). Belajar dan Pembelajaran. Jakarta. Rieneka.

Ensiklopedia Pramuka. (2013). Wide game sebagai Media Pendidikan. Diakses dari www.ensiklopediapramuka.com/2013/06/wide-game-sebaga-media-pendidikan.html (10-11-2020)

Fajuri, F. (2019). Penerapan Pendekatan Cooperative Learning Tipe Jigsaw dalam Upaya Meningkatkan Aktivitas dan Hasil Belajar Peserta Didik Kelas I SD Negeri 27 Ampenan. Jurnal Paedagogy, 6(1), 20-26. doi:https://doi.org/10.33394/jp.v6i1.2526

Hamalik, Oemar. (2013). Proses Belajar Mengajar.Jakarta:Bumi Aksara

Hidayati, Mistina dan Nining Mariyaningsih. 2018. Bukan Kelas Biasa. Surakarta: Kekata Group.

Mulyani, N. (2020). Meningkatkan Aktivitas Belajar Peserta Didik pada Mata Pelajaran PAI dan Budi Pekerti Melalui Pembelajaran Kooperatif Model Mind Mapping dalam Bentuk Peta Konsep Kreatif di SMP Negeri 1 Pemenang. Jurnal Paedagogy, 7(3), 244-251. doi:https://doi.org/10.33394/jp.v7i3.2730

Nurhayati, E. (2020). Meningkatkan Keaktifan Siswa Dalam Pembelajaran Daring Melalui Media Game Edukasi Quiziz pada Masa Pencegahan Penyebaran Covid-19. Jurnal Paedagogy, 7(3), 145-150. doi:https://doi.org/10.33394/jp.v7i3.2645 
Pratini, P. (2015). Upaya Meningkatkan Aktivitas dan Hasil Belajar PKn Siswa Kelas VIII-B SMPN 18 Mataram Melalui Penerapan Pendekatan Cooperative Learning Tipe Jigsaw. Jurnal Kependidikan: Jurnal Hasil Penelitian dan Kajian Kepustakaan di Bidang Pendidikan, Pengajaran dan Pembelajaran, 1(2). doi:https://doi.org/10.33394/jk.v1i2.417

Purwanto. (2010). Evaluasi Hasil Belajar. Yogyakarta: Pustaka Pelajar

Rosidha, A. (2020). Peningkatan Aktivitas dan Hasil Belajar Siswa pada Mata Pelajaran Biologi Melalui Model Pembelajaran Make and Match Berbasis Media Karu Pintar. Jurnal Paedagogy, 7(4), 393-401. doi:https://doi.org/10.33394/jp.v7i4.2946

Subyantoro. (2014). Penelitian Tindakan Kelas. Semarang: Duta Publishing Indonesia

Slameto. (2010). Belajar dan Faktor-Faktor yang Mempengaruhinya. Jakarta. Rieneka Cipta.

Suhardjono, Supardi. (2011). Strategi Menyusun Penelitian Tindakan Kelas. Yogyakarta: ANDI Offset.

Suryani, E. (2018). Meningkatkan Hasil Belajar Ekonomi Melalui Pembelajaran Kooperatif Metode Think Pair Share pada Siswa Kelas XI SMA Negeri 3 Mataram. Jurnal Kependidikan: Jurnal Hasil Penelitian dan Kajian Kepustakaan di Bidang Pendidikan, Pengajaran dan Pembelajaran, 4(2), 141-150. doi:https://doi.org/10.33394/jk.v4i2.1122

Sutikno, Sobry. (2013). Belajar dan Pembelajaran, Upaya Kreatif dalam Mewujudkan Pembelajaran yang Berhasil. Lombok: Holistica.

Suprijono, Agus,. (2010). Cooperative Learning. Yogyakarta. Pustaka Belajar

Trianto. (2007). Model-Model Pembelajaran Inovatif Berorientasi Konstruktivistik. Jakarta: Prestasi Pustaka. 